\title{
Hypoxic neuropathy: relevance to human diabetic neuropathy
}

\author{
R.A.Malik ${ }^{1}$, E. A. Masson ${ }^{2}$, A. K.Sharma ${ }^{1}$, R.H. Lye ${ }^{2}$, A. K. Ah-See ${ }^{1}$, A. M. Compton ${ }^{2}$, D. R. Tomlinson ${ }^{3}$, \\ S.P.Hanley ${ }^{2}$ and A.J.M.Boulton ${ }^{2}$ \\ 1 Departments of Anatomy and Surgery, University of Aberdeen, \\ 2 Departments of Medicine and Neurosurgery, Manchester Royal Infirmary, and \\ ${ }^{3}$ Department of Pharmacology, St. Bartholomew's Hospital, London, UK
}

Summary. Clinical and neurophysiological studies were conducted in 47 patients with chronic obstructive airways disease and compared with 46 age-matched control subjects. Symptomatic neuropathy was reported in $13 \%$ and ankle jerks were absent in $45 \%$ of hypoxic patients. Peroneal and median nerve conduction velocities and median and sural sensory nerve amplitudes were significantly reduced in hypoxic patients $(p<0.01)$. Six hypoxic patients underwent biopsy of the sural nerve, soleus muscle and overlying skin. Nerve glucose, sorbitol, fructose and myo-inositol concentrations were normal. Detailed light and electronmicroscopy revealed both nerve fibre and microvascular pathology. Segmental demyelination $(32 \%)$ and unmyelinated fibre degeneration were found to be prominent lesions. The sural nerve perineu- rium was thickened due to an increase in the number of perineurial lamellae and an increase in intraperineurial space. Basement membrane thickening was observed in capillaries of nerve, muscle and skin. Endothelial cell hyperplasia and hypertrophy were observed in nerve and muscle capillaries but not in skin capillaries. In conclusion, this study has provided neurological, neurophysiological and neuropathological evidence of a neuropathy in hypoxic patients with chronic obstructive airways disease. These findings may be of relevance to some aspects of the aetiology of human diabetic neuropathy.

Key words: Hypoxia, diabetes, neuropathy, microangiopathy.
The pathogenesis of human diabetic neuropathy remains unclear and multiple mechanisms have been postulated [1]. Metabolic [2] and hypoxic [3] mechanisms appear to play a key role in the aetiology of human diabetic neuropathy. Studies on patients with chronic obstructive airways disease may provide relevant information for studying the effects of systemic hypoxia on human peripheral nerve structure and function.

A peripheral neuropathy in such patients was first reported by Appenzeller et al. in 1968 [4]. A number of clinical [5], neurophysiology [6-8] and pathology [4, 8] studies have attempted to define the incidence and characteristics of this peripheral neuropathy. Symptoms range from lower limb paraesthesia [5] to distal sock hypoaesthesia with subsequent motor impairment related to increased severity of disease [9]. Reduced ankle jerks have been reported in patients with minor features of a neuropathy [9] whilst intact ankle jerks have been reported by others in patients with severe airways disease and neuropathy [4]. Neurophysiology studies have demonstrated a reduction in the sensory potential amplitude and distal sensory conduction velocity; with normal [9], slightly abnormal [8] or markedly abnormal [4] motor nerve conduction veloc- ities. Pathology studies have revealed considerable large myelinated fibre loss, axonal degeneration $[4,8]$ and Schwann cell proliferation [4]. Recently, thickening of the basal lamina in both endoneurial and endomysial capillaries has also been reported [8]. Axonal degeneration has also been reported in severely hypoxic patients treated with the respiratory stimulant Almitrine $[10,11]$. In recent studies, we have demonstrated that diabetic nerve is hypoxic in vivo [12] and that extensive microangiopathy with reduced microvascular oxygen diffusing capacity is frequently observed in sural nerve biopsies from diabetic patients [13]. As hypoxia may represent a major contributory factor to the aetiology of human diabetic neuropathy $[3,14]$, we studied non-diabetic hypoxic patients and demonstrated that one of the cardinal features of diabetic neuropathy, resistance to ischaemic conduction failure [14], is hypoxia induced [15].

It therefore appears that previous studies of a peripheral neuropathy in patients with chronic obstructive airways disease have produced somewhat disparate and even contradictory results.

We have conducted a detailed clinical neurophysiological, biochemical and pathological investigation in a large 
Table 1. Standard electrophysiological measures in control subjects and hypoxic patients. (Mean \pm SD)

\begin{tabular}{|c|c|c|c|c|c|c|c|}
\hline & \multirow{2}{*}{$\begin{array}{l}\text { Age (years) } \\
\text { mean [range] }\end{array}$} & \multicolumn{2}{|l|}{ Median nerve } & \multirow{2}{*}{$\begin{array}{l}\text { Peroneal nerve } \\
\text { MNCV } \\
(\mathrm{m} / \mathrm{s})\end{array}$} & \multirow{2}{*}{$\begin{array}{l}\text { Sural nerve } \\
\text { SNAP } \\
(\mu v)\end{array}$} & \multirow{2}{*}{$\begin{array}{l}\text { Vibration } \\
\text { perception } \\
\text { threshold (volts) }\end{array}$} & \multirow{2}{*}{$\begin{array}{l}\text { Thermal } \\
\text { discrimination } \\
\text { threshold }\left({ }^{\circ} \mathrm{C}\right)\end{array}$} \\
\hline & & $\overline{\mathrm{MNCV}}(\mathrm{m} / \mathrm{s})$ & $\overline{\operatorname{SNAP}(\mu v)}$ & & & & \\
\hline $\begin{array}{l}\text { Control subjects } \\
(n=46)\end{array}$ & $58[36-73]$ & $55 \pm 3.1$ & $13.8 \pm 5.6$ & $46.9 \pm 4.6$ & $6.8 \pm 3.9$ & $12.9 \pm 2.2$ & $0.7 \pm 0.55$ \\
\hline $\begin{array}{l}\text { Hypoxic patients } \\
(n=47)\end{array}$ & $62[31-73]$ & $50 \pm 3.6^{\mathrm{b}}$ & $9.7 \pm 4.9^{\mathrm{a}}$ & $42.5 \pm 5.4^{b}$ & $3.4 \pm 3.6^{b}$ & $24.9 \pm 14.0^{\mathrm{b}}$ & $2.9 \pm 5.4^{\mathrm{a}}$ \\
\hline
\end{tabular}

Motor nerve conduction velocity (MNCV) in metres per second (m/s), Sensory nerve action potential amplitude (SNAP) in microvolts ( $\mu \mathrm{v})$. ${ }^{\mathrm{a}}=p<0.005 ;^{\mathrm{b}}=p<0.001$

Table 2. Incidence of isolated teased fibre abnormalities (\%) in chronic hypoxic patients and control subjects. (Mean \pm SEM)

\begin{tabular}{|c|c|c|c|c|c|c|c|}
\hline Patient group & $\begin{array}{l}\text { Normal } \\
\text { fibres }\end{array}$ & $\begin{array}{l}\text { Paranodal } \\
\text { abnormalities }\end{array}$ & $\begin{array}{l}\text { Segmental } \\
\text { demyelination }\end{array}$ & $\begin{array}{l}\text { Segmental } \\
\text { remyelination }\end{array}$ & $\begin{array}{l}\text { Axonal } \\
\text { degeneration }\end{array}$ & $\begin{array}{l}\text { Axonal } \\
\text { regeneration }\end{array}$ & $\begin{array}{l}\text { Total ab- } \\
\text { normal fibres }\end{array}$ \\
\hline $\begin{array}{l}\text { Control subjects } \\
(n=5)\end{array}$ & $93.60 \pm 2.29$ & $1.2 \pm 0.74$ & $1.00 \pm 0.32$ & $1.6 \pm 0.51$ & $1.2 \pm 0.58$ & $1.6 \pm 0.68$ & $4.58 \pm 1.57$ \\
\hline
\end{tabular}

number of hypoxic patients to define the incidence and characteristics of their neuropathy when compared with age-matched control subjects. Such an evaluation may provide further understanding of the possible role of hypoxia in the pathogenesis of human diabetic neuropathy.

\section{Patients and methods}

\section{Patients}

Forty-seven patients ( 30 males, 17 females) with chronic hypoxia (previously documented $\mathrm{PaO}_{2} \leqslant 60 \mathrm{~mm} \mathrm{Hg}(8 \mathrm{KPa})$ ) secondary to obstructive airways disease (chronic bronchitis or emphysema) were studied. All patients had $\mathrm{PaCO}_{2} \leqslant 56 \mathrm{~mm} \mathrm{Hg}(7.5 \mathrm{KPa})$, arterial $\mathrm{pH}$ was normal without respiratory acidosis and at steady state during the study. Detailed examination revealed normal fasting blood glucose and glycosylated haemoglobin levels, negative serology for syphilis, normal serum $B_{12}$, liver function tests and serum creatinine; no history of exposure to neurotoxic chemicals or drugs, no evidence of malignant disease or other causes of neuropathy. Although all these patients had a considerable reduction in exercise tolerance, all were ambulant and none was confined to bed or chair. None of the hypoxic patients had clinical evidence of malnutrition or recent large weight loss. Although some patients were on diuretic therapy, none had significant peripheral oedema, and none had uncontrolled cardiac failure. Control data was obtained from 46 age-matched control subjects who were either healthy volunteers or hospital patients with no history of neurological or respiratory disease.

\section{Neurophysiology}

In addition to standard neurological history and examination, motor nerve conduction velocities were measured in the median and peroneal nerves using surface electrodes and a Medelec MS92A electrophysiological system (Medelec Ltd., Old Woking, UK). Sensory nerve conduction and amplitude were also assessed in the median and sural sensory nerves. The Medelec system employs normalised computer averaging with automatic artefact rejection. The maximum display sensitivity is 0.1 microvolts/division. A maximum of 32 sweeps was used for data acquisition of sensory action potentials. Vibration perception threshold was assessed over the great toe using a biothesiometer [16] (Bio-Medical Instrument Company, Ohio, U.S.A.) employing a length calibrated instrument. Thermal (warming) perception threshold were measured on the flexor surface of the wrist and on the dorsum of the foot using a thermo-aesthaesiometer (Free University, Amsterdam, The Netherlands). A forced choice method was used [17]. All neurophysiological assessments were carried out after patients were made comfortable in a warm environment and skin temperatures were maintained above $30^{\circ} \mathrm{C}$.

Minimal criteria for peripheral neuropathy were defined as two or more electrophysiological abnormalities (relative to laboratory normal range), plus either absent ankle reflexes, or diminished vibration perception [18].

\section{Tissue biopsy}

Six unselected hypoxic patients with abnormalities of electrophysiological and sensory tests underwent biopsy of the sural nerve, soleus muscle and overlying skin under local anaesthesia (lignocaine $2 \%$ ) after approval from the Central Manchester Hospitals Ethical Committee. The nerve segment was immediately divided into two, a portion being frozen in liquid nitrogen and subsequently stored at $-70^{\circ} \mathrm{C}$ for biochemical analysis and the other was fixed and dehydrated through immersion for light and electronmicroscopy, including teased fibre preparations according to previously described standardized techniques [19]. The muscle and skin specimens were also immediately fixed and processed for light and electronmicroscopy using previously described methods [13] and compared with control biopsies obtained from brain dead transplant donors and traumatic amputees; in whom electrophysiological and other investigations were not feasible at the time of biopsy.

\section{Biochemicalmethods}

The concentrations of glucose, sorbitol, fructose and myo-inositol were assayed by gas liquid chromatography of their trimethylsilyl derivatives according to previously described methods [20]. Samples were run on a Shimadzu GC-8A gas chromatograph (Shimadzu Analytical instruments, Kyoto, Japan) fitted with a $25 \mu \mathrm{m}$ fused silica capillary column $25 \mathrm{~m}$ in length (J and W Scientific Inc., Rancho Cordova, Calif, USA) using alpha-methyl D-Mannoside as an internal standard.

\section{Histological and morphometric procedures}

Single teased fibres were isolated in unpolymerised Epon and mounted on glass slides in catalysed Epon for assessment of abnormalities using previously described criteria [21]. Semithin and ultra- 


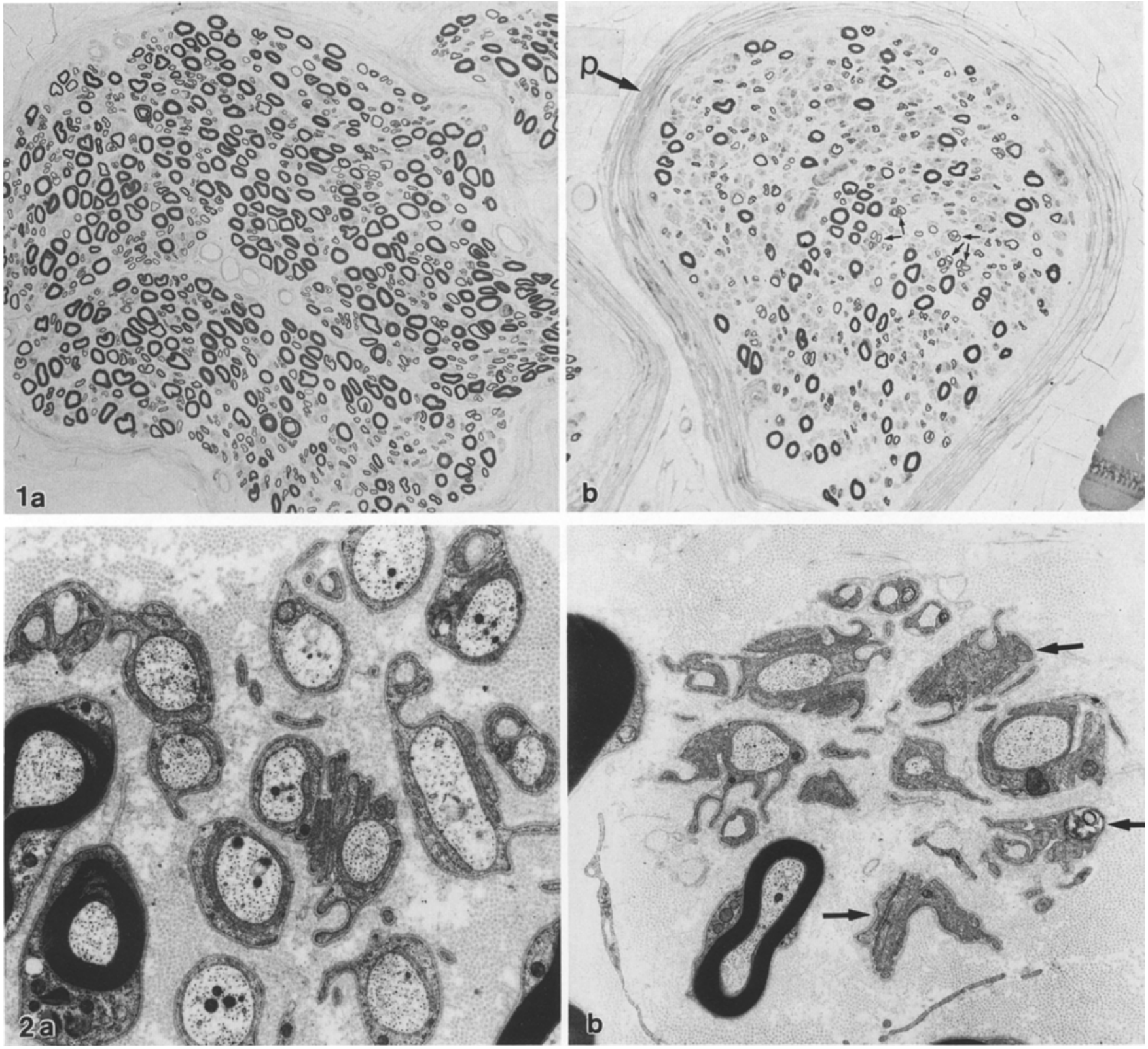

Fig. 1 a, b. a Transverse section of normal sural nerve $\times 300$; b Transverse section of sural nerve from a hypoxic patient $\times 300$ showing thickening of the perineurial sheath $(p)$, reduction of myelinated fibre density and regenerative clusters (arrows)

Fig. 2 a, b. a Electronmicrograph of normal sural nerve showing dense population of unmyelinated fibres $(\times 6000)$; b Electronmicrograph of sural nerve from a hypoxic patient showing Schwann cell processes without axons (arrows) $(\times 6000)$

thin sections were cut on a Reichert OMU4 ultracut ultramicrotome and stained with thionin and acradine orange and methanolic uranyl acetate/lead citrate respectively. Myelinated fibre density and fasicular area were derived from montages of all fasicles in the sural nerve using a camera lucida and a direct count. A systematic random sampling procedure was employed to produce electronmicrographs of myelinated fibres $(\times 4000)$ unmyelinated fibres $(\times 10000)$ and perineurium $(\times 3000, \times 18000)$. Myelinated fibre and axon diameters, and unmyelinated fibre axon diameter were assessed from electronmicrographs using a magnetostrictive digitizer interfaced to a $\mathrm{BBC}$ microcomputer system. The unmyelinated fibre density and the number of axons per Schwann cell profile were counted directly from electronmicrographs $(\times 10000)$. Detailed microvascular pathology was assessed from electronmicrographs of all capillaries in view from nerve $(\times 8000)$ skin $(\times 8000)$ and muscle $(\times 12000)$ using previously described rationale to differentiate capillaries, and stereological methods to assess quantitative microvascular pathology [13]. Perineurial pathology was assessed from random intercept lengths for the perineurial sheath (outer border of perineurium to inner border of perineurium), perineurial cell (outer border of perineurial cell to inner border of perineurial cell) and basement membrane (outer free border of basement membrane to perineurial cell membrane) were digitized employing a magnetostrictive digitizer interfaced to a $\mathrm{BBC}$ microcomputer system. The number of perineurial cell lamellae were counted directly from each electronmicrograph. The intraperineurial space (Ips) was derived from the formula:

Ips $=($ Tpt $)-(($ Pct $\times 1)+($ bmt $\times((1-1) \times 2))$

Where Tpt represents the mean perineurial sheath thickness, Pct is 


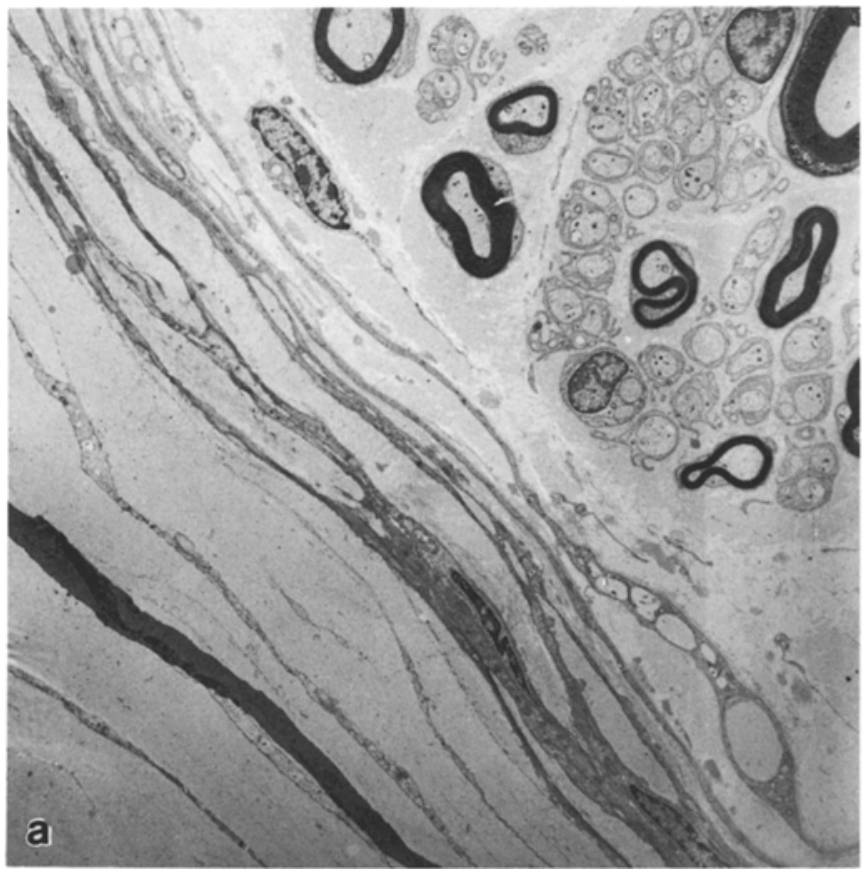

Fig. 3 a, b. a Electronmicrograph of normal sural nerve showing perineurial sheath $(\times 2000)$; b Electronmicrograph of sural nerve from a hypoxic patient showing thickening of the perineurial sheath and an increase in the number of perineurial lamellae (PI) and intraperineurial space (Is) $(\times 2000)$

the mean perineurial cell thickness, bmt is the mean perineurial cell basement membrane thickness and 1 is the mean number of perineurial cell lamellae in the perineurial sheath.

\section{Statistical analysis}

All neurophysiological data were compared using the two-tailed Mann-Whitney U-test employing the Amstat statistical package for Amstrad computers (S. C. Coleman Ltd., Ashby-de-la-Zouch, Leics, UK). Pathological results were compared using the two-tailed Mann-Whitney U-test employing the Minitab statistical package on the University of Aberdeen Honeywell-Bull DPS8770 mainframe computer system.

\section{Results}

\section{Clinical}

Symptoms typical of peripheral neuropathy (eg. paraesthaesia, dysaesthesia, burning pain) were reported in $13 \%$ of hypoxic subjects and ankle jerks were absent in $45 \%$ of these patients. A reduction or absence of fine touch and vibration sensation was observed in $41 \%$ of hypoxic patients. The control subjects had no symptoms or signs of peripheral neuropathy.

\section{Neurophysiological}

The patients and control subjects were age-matched, and abnormalities of all principal electrophysiological parameters found are summarised in Table 1 . Peroneal and median nerve conduction velocities were significantly re-

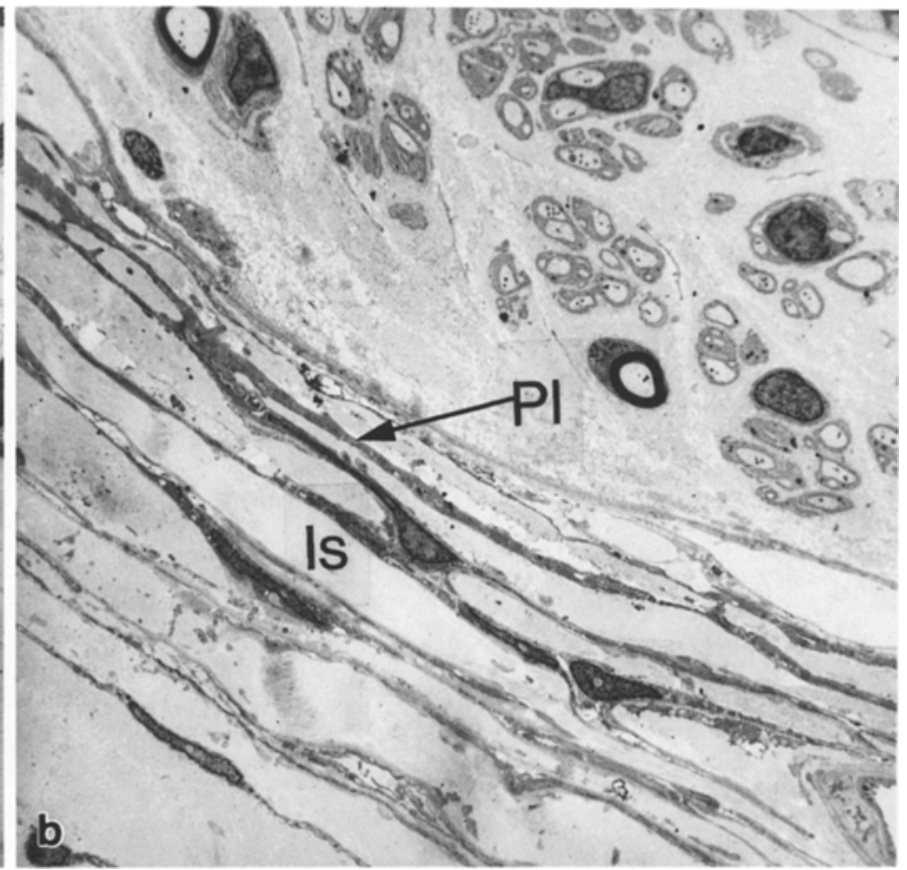

duced in hypoxic patients $(p<0.001)$. Median $(p<0.005)$ and sural $(p<0.001)$ nerve sensory amplitudes were also significantly reduced in hypoxic patients. 'Objective' measures of sensory perception revealed abnormalities in the lower limb: vibration $(p<0.001)$ and thermal $(p<0.005)$ perception thresholds at the hallux were significantly higher in hypoxic patients compared with control subjects.

\section{Biopsy findings}

The mean age of control biopsy subjects was $56.5 \pm 9.9$ (Mean \pm SEM) years compared with $64.6 \pm 2.15$ (Mean \pm SEM) years for the biopsied hypoxic patients.

Considerable pathology was observed in myelinated fibres (Fig. 1), unmyelinated fibres (Fig.2) and the perineurium (Fig. 3) of hypoxic patients when compared with control subjects. Both regenerative clusters, indicative of axonal regeneration, and thinly myelinated fibres, indicative of remyelination, were observed qualitatively (Fig. 1b) in hypoxic patients.

\section{Myelinated fibres}

Teased fibre preparations showed paranodal abnormalities (demyelination and remyelination in the paranodal region with widening of the nodal gap), marked segmental demyelination and remyelination (32\%) and slight axonal degeneration and regeneration $(5.9 \%)$ in the sural nerve of hypoxic patients (Table 2). Mean myelinated fibre density, mean fibre and its axonal diameter were not significantly reduced in hypoxic patients when compared with control subjects (Fig. 4 a). The percentage of fibres $\leqslant 6 \mu \mathrm{m}(78 \%$ vs $79.5 \%)$ and $\geqslant 6 \mu \mathrm{m}(22 \%$ vs $21.5 \%)$ were not different between control and hypoxic nerves respectively. Therefore, there was no selective small or large fibre loss. 

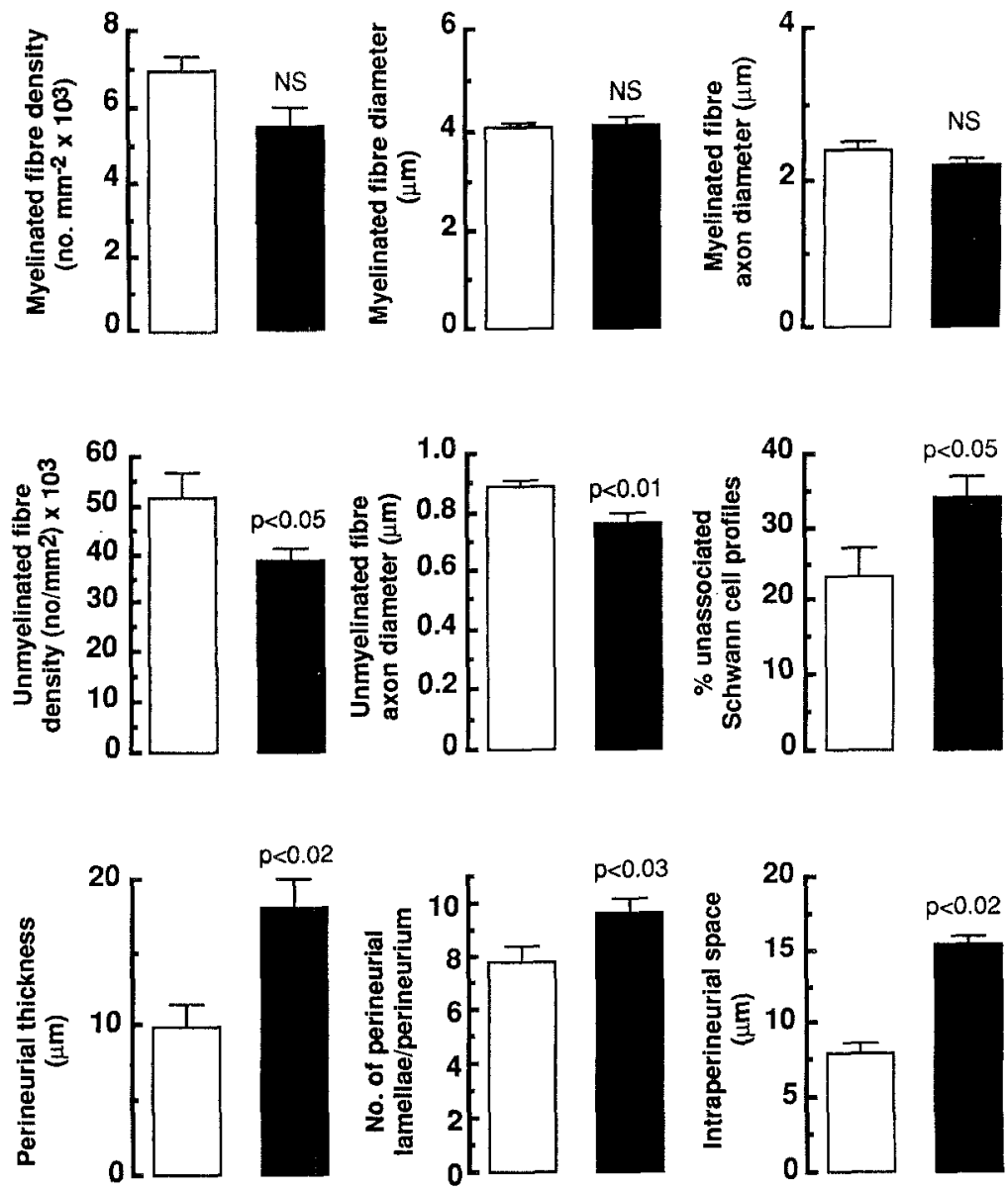

Fig.4. Myelinated fibre density and myelinated fibre and axon diameter (upper panel); Unmyelinated axon density and their diameter and percentage of Schwann cell profiles without axons (middle panel); Perineurial sheath thickness, number of perineurial lamellae and the intraperineurial space (lower panel) in the sural nerve of control subjects $\square$ and hypoxic patients $\boldsymbol{\varpi}$.

(Mean \pm SEM)

\section{Unmyelinated fibres}

Unmyelinated fibre degeneration occurred as there was an increase in the percentage of Schwann cell profiles without axons $(p<0.05)$, reduction in axon density $(p<0.05)$ and reduced mean axon diameter $(p<0.01)$ in hypoxic nerves (Fig. $4 \mathrm{~b}$ ). The distribution of the number of axons per Schwann cell profile and the size frequency distributions of unmyelinated axons were no different in hypoxic patients when compared with control subjects (Fig.5), suggesting a lack of axonal sprouting.

\section{Perineurium}

The sural nerve perineurium was significantly thickened in hypoxic patients $(p<0.02)$. Both the number of perineurial cell lamellae $(p<0.03)$ and the intraperineurial space $(p<0.02)$ were significantly increased in hypoxic patients (Fig. 4c). The thickness of perineurial cells and their basement membrane were not significantly different in hypoxic patients when compared with control subjects.

\section{Endoneurial capillaries}

The mean sural nerve fasicular area in hypoxic patients was not different from control subjects. Endoneurial capillary density and estimated oxygen diffusing capacity were slightly but not significantly reduced in hypoxic nerves.
Endothelial cell profile number $(p<0.005)$ and nuclear number $(p<0.03)$, luminal $(p<0.02)$ and vessel $(p<0.02)$ perimeters; and capillary wall thickness $(p<0.03)$ were significantly increased in hypoxic patients.

Endothelial cell outer perimeter was not significantly different between hypoxic patients and control subjects. Both endothelial cell thickness and basement membrane thickness were increased but failed to attain a statistically significant difference when compared with control subjects (Table 3 ).

\section{Muscle capillaries}

Muscle capillaries showed increased endothelial cell profile number $(p<0.02)$ and thickness $(p<0.01)$ with increased basement membrane $(p<0.01)$ and capillary wall $(p<0.01)$ thickness (Table 3$)$.

\section{Skin capillaries}

Skin capillaries demonstrated slight but non-significant increases in endothelial cell profile number and endothelial cell thickness in hypoxic patients. Both the basement membrane $(p<0.005)$ and capillary wall $(p<0.008)$ were markedly thickened in hypoxic patients when compared with control subjects (Table 3). 

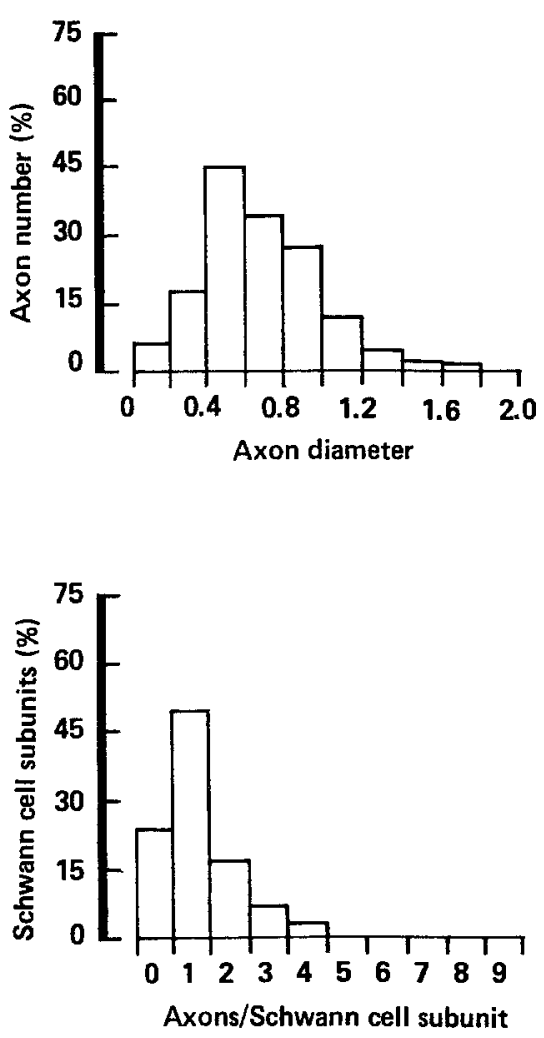
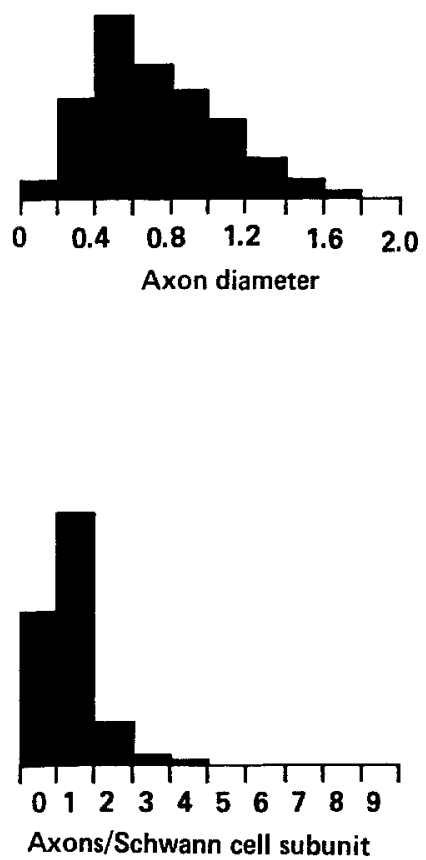

Fig.5. Unmyelinated axon size frequency distribution (upper panel) and distribution of number of axons per Schwann cell subunit (lower panel) in control subjects left side and hypoxic patients right side

\section{Biochemical}

Concentrations of nerve glucose $(6.81 \pm 0.35 \mathrm{nmol} / \mathrm{mg})$ and fructose $(0.36 \pm 0.06 \mathrm{nmol} / \mathrm{mg})$ were found to be within the normal range [22]. Sorbitol was detected at a very low concentration $(<0.01 \mathrm{nmol} / \mathrm{mg})$ and myo-inositol levels $(4.91 \pm 0.18 \mathrm{nmol} / \mathrm{mg})$ were not reduced [23].

\section{Discussion}

Inappropriate patient selection, differing methods of clinical and neurophysiological assessment, and qualitative rather than quantitative estimates of pathological lesions have produced somewhat contradictory data on the prevalence and characteristics of a peripheral neuropathy in patients with chronic obstructive airways disease.

A distal, symmetrical and predominantly sensory polyneuropathy of the lower limbs with hypoaesthesia, paraesthesia and spontaneous pain has been reported in $14-40 \%$ of hypoxic patients $[4,6,8]$. A lower incidence of symptomatic neuropathy $(13 \%)$ was observed in the present study because it represents the incidence in the general population of hypoxic patients as opposed to selected groups in previous studies [4]. Ankle jerks were absent in $45 \%$ of individuals, comparable with most other studies [6, $7,9]$. In the present study, motor and sensory nerve conduction velocities were reduced, together with a reduction in sensory nerve amplitudes, confirming previous observations $[6,8,9]$. However, our findings failed to agree with the observation of preserved nerve conduction and predominant electromyograph and nerve amplitude abnormalities considered to reflect a motor neurone lesion [7].
Neuropathological changes are not clearly established in patients with chronic obstructive airways disease. In the teased fibre preparation, we have demonstrated a significantly greater number of myelinated fibres undergoing segmental demyelination and remyelination. Significant axonal degeneration or myelinated fibre loss was not observed. Appenzeller et al. [4] have reported large myelinated fibre loss, non-specific changes in size frequency distributions and a combination of both axonal degeneration and segmental demyelination in longitudinal sections but not in teased fibre preparations. Recently, Paramelle et al. [8] have reported predominant axonal degeneration and large fibre loss with slight segmental demyelination. This study has also demonstrated unmyelinated fibre degeneration in the form of reduced axon density and size with an increase in the number of Schwann cell profiles without axons. Previous studies have failed to quantify unmyelinated fibre pathology $[4,8]$. Appenzeller et al. [4] have reported an increase in the interstitial space, suggestive of endoneurial expansion. This study failed to reveal fasicular expansion. An increase in interstitial space may, therefore, have simply reflected a loss of nerve fibres.

A thickening of muscle and nerve capillary basement membrane has been demonstrated, but it was not assessed quantitatively and was also not compared with control subjects [8]. This study has quantified endothelial cell and basement membrane pathology and has shown significant differences in the capillaries of nerve, muscle and skin from hypoxic patients when compared with control subjects. Endothelial cell hyperplasia, suggestive of a hypoxic basis for endothelial proliferation was demonstrated. A failure of the endoneurial capillaries to increase in size to 
Table 3. Morphometric measurements $(\overline{\mathrm{X}} \pm \mathrm{SEM})$ of capillaries from nerve, muscle and skin in control subjects and hypoxic patients

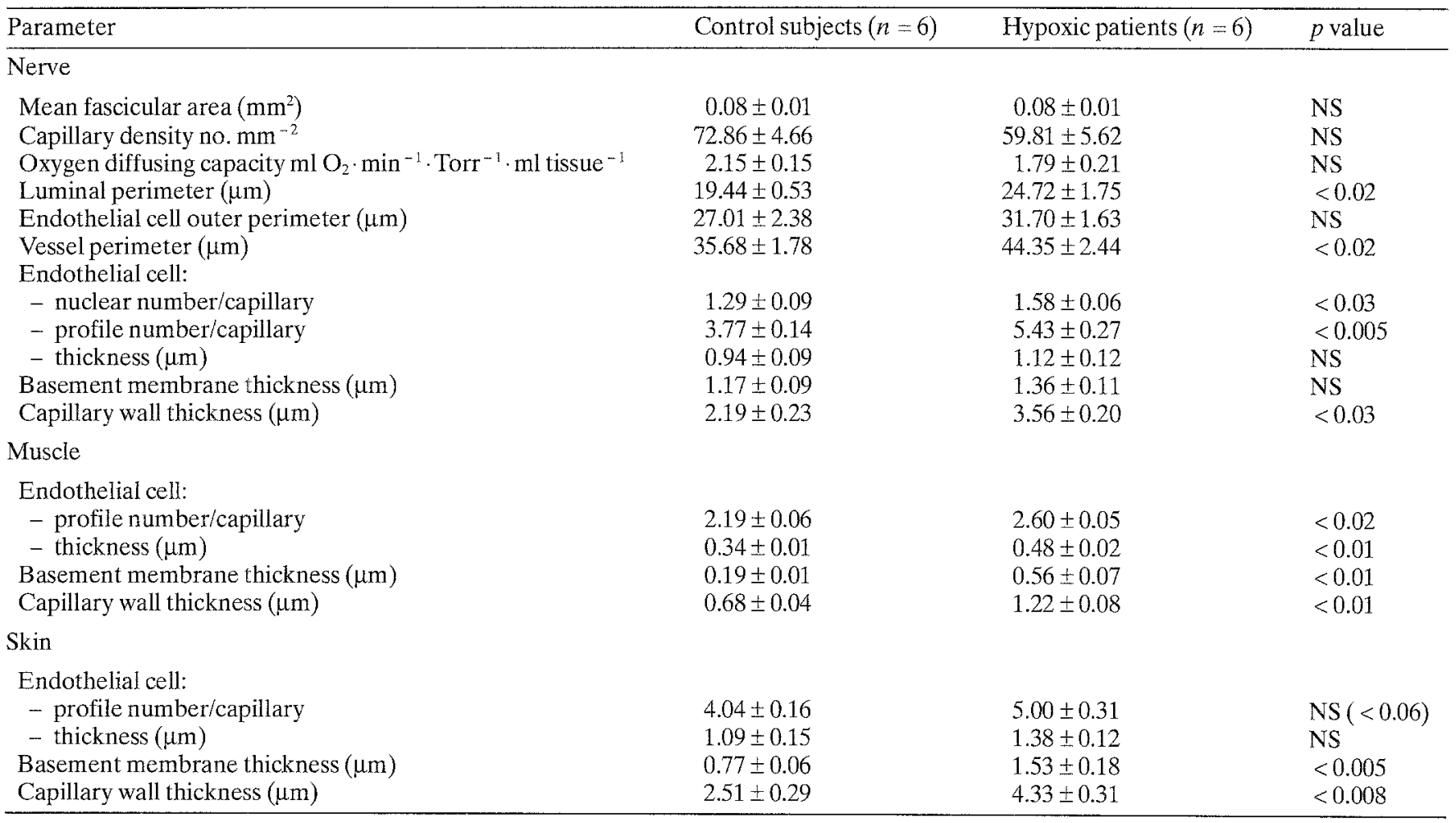

accommodate endothelial cell hyperplasia and hypertrophy predisposes such capillaries to luminal occlusion. This study has also established a characteristic thickening of sural nerve perineurium in patients with hypoxic neuropathy which may further impede the transport of nutrients and oxygen and hence alter nerve function and structure [24].

Chronic hypoxia in normal rats has been shown to produce electrophysiological abnormalities similar to those observed in experimental diabetic rats in the absence of hyperglycaemia, nerve sorbitol accumulation and myo-inositol reduction [25]. The characterization of neuropathy in hypoxic patients may therefore have relevance and may also provide support for the recent reappraisal of the role of hypoxia in the development of human diabetic neuropathy $[3,13,14]$. The present study has revealed neurophysiological abnormalities similar to those observed in human diabetic neuropathy [16-18]. Morphology studies showed segmental demyelination in hypoxic patients which is also found in asymptomatic neurophysiologically normal diabetic patients $[23,26]$. Current evidence indicates an independent effect of the diabetic state on both axon and Schwann cell function and structure $[27,28]$. Thus, hypoxia may contribute to the component of the diabetic state which is responsible for segmental demyelination. Unmyelinated fibre degeneration was observed in hypoxic neuropathy and it is a characteristic feature of both early [26] and established human diabetic neuropathy $[19,27]$. Microvascular abnormalities, namely, endothelial cell hyperplasia and hypertrophy with basement membrane thickening ultimately predispose the capillaries to luminal narrowing and vascular occlusion producing added hypoxic insult in hypoxic neuropathy. Simi- lar findings have been reported in human diabetic neuropathy $[13,29,30]$.

In conclusion, this study has revealed clinical, neurophysiological and neuropathological evidence of a neuropathy in hypoxic patients. These findings may therefore be of relevance to some aspects of the aetiology of human diabetic neuropathy.

Acknowledgements. We would like to thank Prof. S. Tomlinson, Department of Medicine, Manchester Royal Infirmary and Professor E.J.Clegg, Department of Anatomy, Aberdeen University for their constant support and encouragement; and Dr. T. B. Stretton for permission to study his patients. We also thank Mrs. M. Moir for typing the manuscript. Drs. E. A. Masson and A.J.M.Boulton were supported in part by the Wellcome Trust.

\section{References}

1. Ward JD (1989) Diabetic neuropathy. Diabetes. Br Med Bull 5: $111-126$

2. Greene DA, Lattimer SA, Sima AAF (1987) Sorbitol phosphoinositides and sodium potassium ATPase in the pathogenesis of diabetic complications. N Engl J Med 316: 599-606

3. Dyck PJ (1989) Hypoxic neuropathy: does hypoxia play a role in diabetic neuropathy? Neurology $39: 111-118$

4. Appenzeller O, Parks RD, MacGee J (1968) Peripheral neuropathy in chronic disease of the respiratory tract. Am J Med 44: $873-880$

5. Kinsman RA, Yaroush RA, Fernandez E, Dirks JF, Schocket M, Fukihara J (1983) Symptoms and experiences in chronic bronchitis and emphysema. Chest 83: 755-761

6. Narayan M, Ferranti R (1978) Nerve conduction impairment in patients with respiratory insufficiency and severe chronic hypoxemia. Arch Phys Med Rehabil 59: 188-192 
7. Valli G, Barbieri S, Sergi P, Fayoumi Z, Berardinelli P (1984) Evidence of motor neurone involvement in chronic respiratory insufficiency. J Neurol Neurosurg Psychiatry 47: 1117-1121

8. Paramelle B, Vila A, Pollak P, Muller P, Gavelle D, Reymond F, Brambilla C, Stoebner $P$ (1986) Frequence des polyneuropathies dans les bronchopneumopathies chroniques obstructive. La Presse Medicale 12: 563-567

9. Faden A, Mendoza E, Flynn F (1981) Subclinical neuropathy associated with chronic obstructive pulmonary disease: possible pathophysiologic role of smoking. Arch Neurol 38: 639-642

10. Gherardi R, Benvenuti C, Lejonc JL, Louarn F, Perrier M, Schaeffer A, Degos JD (1985) Peripheral neuropathy in patients treated with almitrine dismesylate. Lancet I: $1247-1250$

11. Chedru F, Nodzenski R, Durard JF (1985) Peripheral neuropathy during treatment with almitrine. Br Med J 290: 890

12. Newrick PG, Wilson AJ, Jakubowski J, Boulton AJM, Ward JD (1986) Sural nerve oxygen tension in diabetes. Br Med J 293: 1053-1054

13. Malik RA, Newrick PG, Sharma AK, Jennings A, Ah-See AK, Mayhew TM, Jakubowski J, Boulton AJM, Ward JD (1989) Microangiopathy in human diabetic neuropathy: relationship between capillary abnormalities and the severity of neuropathy. Diabetologia 32: 92-102

14. Low PA, Tuck RR, Takeuchi M (1987) Nerve microenvironment in diabetic neuropathy. In: Dyck PJ, Thomas PK, Asbury AK, Winegrad AI, Porte D (eds) Diabetic neuropathy. Saunders, Philadelphia, pp 266-278

15. Masson EA, Church SE, Woodcock AA, Hanley SP, Boulton AJM (1988) Is resistance to ischaemic conduction failure induced by hypoxia? Diabetologia 31: 762-765

16. Boulton AJM, Hardisty CA, Betts RP, Frank CI, Worth RC, Ward JD, Duckworth T (1983) Dynamic foot pressure and other studies as diagnostic aids in diabetic neuropathy. Diabetes Care 6: $26-33$

17. Bertelsmann FW, Heimans JJ, Weber EJM, Van der Veen EA, Schouten JA (1985) Thermal discrimination thresholds in normal subjects and in patients with diabetic neuropathy. $J$ Neurol Neurosurg Psychiatry 48: 686-690

18. Dyck PJ, Karnes J, O'Brien PC (1987) Diagnosis, staging and classification of diabetic neuropathy and associations with complications. In: Dyck PJ, Thomas PK, Asbury AK, Winegrad AI, Porte D (eds) Diabetic neuropathy. Saunders, Philadelphia, pp 36-44

19. Archer AG, Watkins PJ, Thomas PK, Sharma AK, Payan J (1983) The natural history of acute painful neuropathy in diabetes mellitus. J Neurol Neurosurg Psychiatry 46: 491-499
20. Lambourne JE, Tomlinson DR, Brown AM, Willars GB (1987) Opposite effects of diabetes and galactosaemia on adenosine triphosphate activity in rat nervous tissue. Diabetologia 30 : 360-362

21. Sharma AK, Bajada S, Thomas PK (1980) Age changes in the tibial and plantar nerves of the rat. J Anat 130: 417-428

22. Hale PJ, Nattrass M, Silverman SH, Sennit C, Perkins CM, Uden A. Sundkvist G (1987) Peripheral nerve concentrations of glucose, fructose, sorbitol and myo-inositol in diabetic and nondiabetic patients. Diabetologia 30:464-467

23. Dyck PJ, Sherman WR, Hallcher LM, Service JF, O'Brien P, Grisa LS, Palumbo PJ, Swanson CJ (1980) Human diabetic endoneurial sorbitol, fructose and myo-inositol related to sural nerve morphometry. Ann Neurol 8: 590-596

24. Thomas PK, Olsson Y (1984) Microscopic anatomy and function of the connective tissue components of peripheral nerve. In: Dyck PJ, Thomas PK, Lambert EH, Bunge R (eds), Peripheral neuropathy. Saunders, Philadelphia, pp 97-120

25. Low PA, Schmelzer JD, Ward KK, Yao JK (1986) Experimental chronic hypoxic neuropathy - relevance to diabetic neuropathy. Am J Physiol 280: E94-E99

26. Malik RA, Ah-See AK, Newrick PG (1988) Nerve fibre and microvascular abnormalities in non-neuropathic, asymptomatic diabetic patients. Diabetes 37: 480 Abstract

27. Behse F, Bucthal F, Carlsen F (1977) Nerve biopsy and conduction studies in diabetic neuropathy. J Neurol Neurosurg Psychiatry 40: 1072-1079

28. Sugimura K, Dyck PJ (1981) Sural nerve myelin thickness and axon cylinder caliber in human diabetes. Neurology 31 : 1087-1092

29. Dyck PJ, Hansen S, Karnes J, O'Brien P, Yasuda H, Windebank A, Zimmerman B (1985) Capillary number and percentage closed in human diabetic sural nerve. Proc Natl Acad Sci USA 82: 2513-2517

30. Yasuda H, Dyck PJ (1987) Abnormalities of endoneurial microvessels and sural nerve pathology in diabetic neuropathy. Neurology $37: 20-28$

Received: 13 July 1989

and in revised form: 21 December 1989

Dr. A.J.M. Boulton

Department of Medicine

Manchester Royal Infirmary

Manchester M13 9WL

UK 